\title{
Topografi Organ-Organ Visceral Ular Koros (Ptyas mucosus)
}

\author{
Visceral Organs Topography of Koros Snake (Ptyas mucosus)
}

\author{
Annawaty \\ Program Studi P. Biologi Jurusan P. MIPA FKIP Universitas Tadulako Palu Sulawesi Tengah 92000, \\ E-mail: Hakining@Yahoo.com
}

Ular dianggap berkerabat dekat dengan kadal berdasarkan anatomi perbandingan yang memperlihatkan kemiripan struktur di antara mereka. Beberapa ahli zoologi berasumsi bahwa moyang ular merupakan hewan sebangsa kadal yang dahulunya hidup di liang. Pola hidup di liang dengan menggali lubang di dalam tanah, membuat mereka tidak begitu memanfaatkan kedua pasang tungkainya sehingga lama-kelamaan mengalami penyusutan dan akhirnya berdegenerasi. Pada beberapa kelompok ular primitif, yaitu ularular yang keberadaannya di bumi lebih awal dalam perhitungan skala waktu geologi, masih dijumpai adanya sisa tungkai yang berbentuk taji di dekat kloaka, seperti pada Familia Boidae, yaitu: ular Pyton dan ular Boa, sedangkan gelang panggul masih terdapat pada Familia Typhlopidae (Anonim, 1988; Gibbons 1988).

Seiring dengan perjalanan evolusinya, tubuh ular yang menjadi lebih panjang selanjutnya mempengaruhi topografi organorgan visceralnya. Secara umum ular memiliki organ dalam yang berpasangan seperti halnya pada kerabatnya yaitu kadal. Namun demikian pada ular, bentuk dan letak antar organ yang berpasangan menampakkan ciri yang unik. Parker (1977) melaporkan bahwa pada ular Pyton molurus organ-organ visceral memanjang mengikuti bentuk tubuh ular, sedangkan ukuran panjang paru-paru kiri jauh lebih kecil dibnadingkan paru-paru kanan.

Salah satu jenis ular yang sering dijumpai adalah ular Koros (Ptyas mucosus), karena ular ini menyenangi habitat persawahan, ladang dan hutan. Secara morfologi Ular Koros ditandai dengan bentuk tubuh yang memanjang dengan panjang badan dapat mencapai $250 \mathrm{~cm}$, warna dasar bagian dorsal coklat tua, sisik ventral putih kekuningan dengan sisik ventral subcaudal berpasangan, sisik-sisik dorsal bertakik, serta sisik-sisik bibir bertepi hitam.

Penelitian ini merupakan hasil penelitian awal untuk mengungkap bagaimana topografi organ-organ visceral ular Koros. Sampel ular Koros yang dianalisa sebanyak tiga spesimen dengan panjang berkisar antara $178-200 \mathrm{~cm}$. Spesimen ini berasal dari daerah Kwarasan Sleman Yogyakarta yang dikoleksi sejak Bulan November 2002.

Sebelum diamati, ular terlebih dahulu dibius dengan kloroform, kemudian dimasukkan ke dalam formalin $4 \%$ selama 24 jam. Setelah itu dicuci dalam air mengalir selama 48 jam lalu dimasukkan ke dalam alkohol $70 \%$ Pengamatan dilakukan dengan cara melakukan pembedahan yang dimulai dari bagian kloaka. Kulit di sekeliling kloaka di sayat secara melingkar, sementara itu kulit di bagian ventral disayat ke arah anterior. Kulit dilepas perlahan-lahan dari jaringan lemak di bagian ventral, kemudian dibersihkan sehingga organ-organ dalam menjadi tampak. Pengamatan dilakutkan pada letak antar organorgan visceral ular Koros serta posisi organorgan tersebut antara satu dengan yang lain, kemudian didokumentasi dengan foto dan dibuat sketsanya.

Berdasarkan pembedahan yang telah dilakukan pada tiga spesimen ular koros tersebut, didapatkan hasil bahwa organ-organ visceral ular Koros bentuknya memanjang mengikuti bentuk tubuhnya yang juga memanjang. Deskripsi organ-organ visceral tersebut adalah sebagai berikut:

1. Trachea berbentuk memanjang dan berhubungan dengan pulmo yang lobusnya juga berbentuk memanjang .

2. Cor terletak di ventral pulmo 
3. Hepar berlobus dua memanjang, lobus kanan lebih panjang daripada lobus kiri. Letak hepar di posterior pulmo, hepar bagian anterior bersinggungan dengan bagian posterior pulmo

4. Vesica fellea tidak melekat pada hepar tetapi bersama-sama dengan lien dan pankreas melekat pada ujung posterior ventriculus yang berhubungan dengan intestinum.

5. Ren berjumlah sepasang dengan bentuk bulat memanjang. Ren kanan dan ren kiri letaknya tidak simetris. Ren kanan terletak di anterior ren kiri. Ukuran panjang ren kanan lebih besar daripada ren kiri.

6. Pulmo kiri telah mengalami degenerasi (menghilang) sehingga ular Koros hanya memiliki satu pulmo yang berfungsi yaitu pulmo kanan.

7. Testis sepasang dengan letak yang tidak simetris. Testis kanan terletak di anterior testis kiri. Ukuran panjang testis kanan lebih besar daripada testis kiri

Berikut ini adalah topografi organ-organ visceral ular Koros secara skematis.

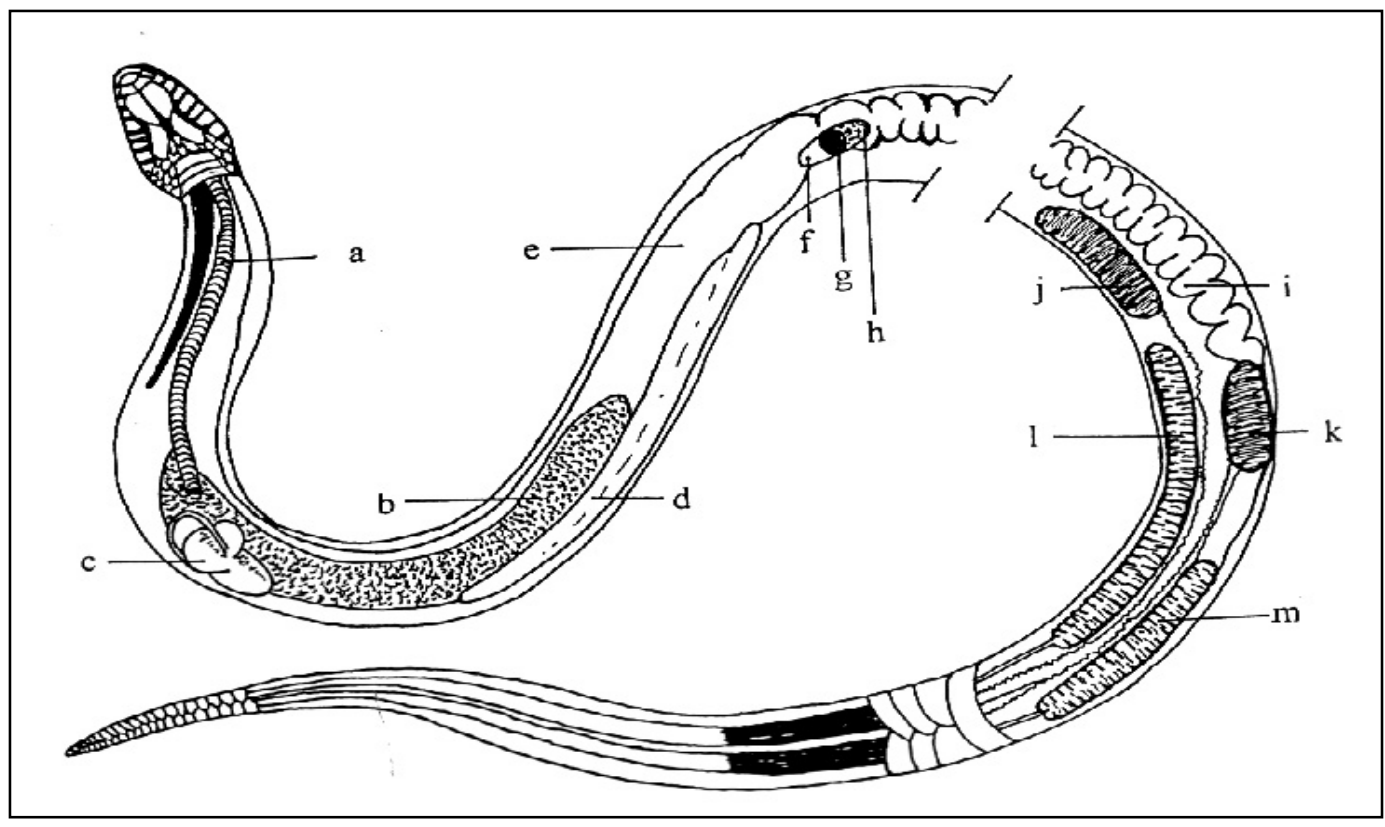

Gambar 1. Skema topografi Organ-Organ Visceral ular Koros (Ptyas mucosus)
Keterangan:
a). trachea
b). pulmo kanan
c). cor
d). hepar
e). ventriculus
f). vesica fellea
g). lien
h). pankreas
i). intestinum
j). testis kanan
$\mathrm{k})$. testis kiri
1). ren kanan
m). ren kiri

\section{Daftar Pustaka}

Anonim. 1988. Ensiklopedia Indonesia Seri Fauna Reptilia dan Ampibia. Cetakan I. P.T. Dai Nippon Printing Indonesia. Jakarta.
Gibbons, J.W. 1988. Snake In: www.comptons.com. Compton`s Encyclopedia Online v3.0 (C). The Learning Company, Inc.

Parker, H.W. 1977. Snakes a Natural History. $2^{\text {nd }}$ edition. British Museum (Natural History) and Cornell University Press. London. 